\title{
Water Resources of St. Bernard Parish, Louisiana
}

\section{Introduction}

In 2010, about 261 million gallons per day (Mgal/d) of water were withdrawn in St. Bernard Parish, Louisiana (fig. 1), almost entirely from surface-water sources ${ }^{1}$ (table 1 ). Industrial use accounted for about 97 percent $(253 \mathrm{Mgal} / \mathrm{d})$ of the total water withdrawn. Other categories of use included public supply, rural domestic, and livestock (table 2). Water-use data

${ }^{1}$ Tabulation of numbers in text and tables may result in different totals because of rounding; nonrounded numbers are used for calculation of totals. collected at 5-year intervals from 1960 to 2010 indicated that total water withdrawals in the parish ranged from about 138 to $720 \mathrm{Mgal} / \mathrm{d}$ (fig. 2), with industrial use of surface water making up the bulk of water withdrawals. The large decline in surfacewater withdrawals from 1980 to 1985 was largely attributable to a decrease in industrial use from $654 \mathrm{Mgal} / \mathrm{d}$ in 1980 to $127 \mathrm{Mgal} / \mathrm{d}$ in 1985.

This fact sheet summarizes basic information on the water resources of St. Bernard Parish. Information on groundwater and surface-water availability, quality, development, use, and trends is based on previously published reports listed in the Selected References section.

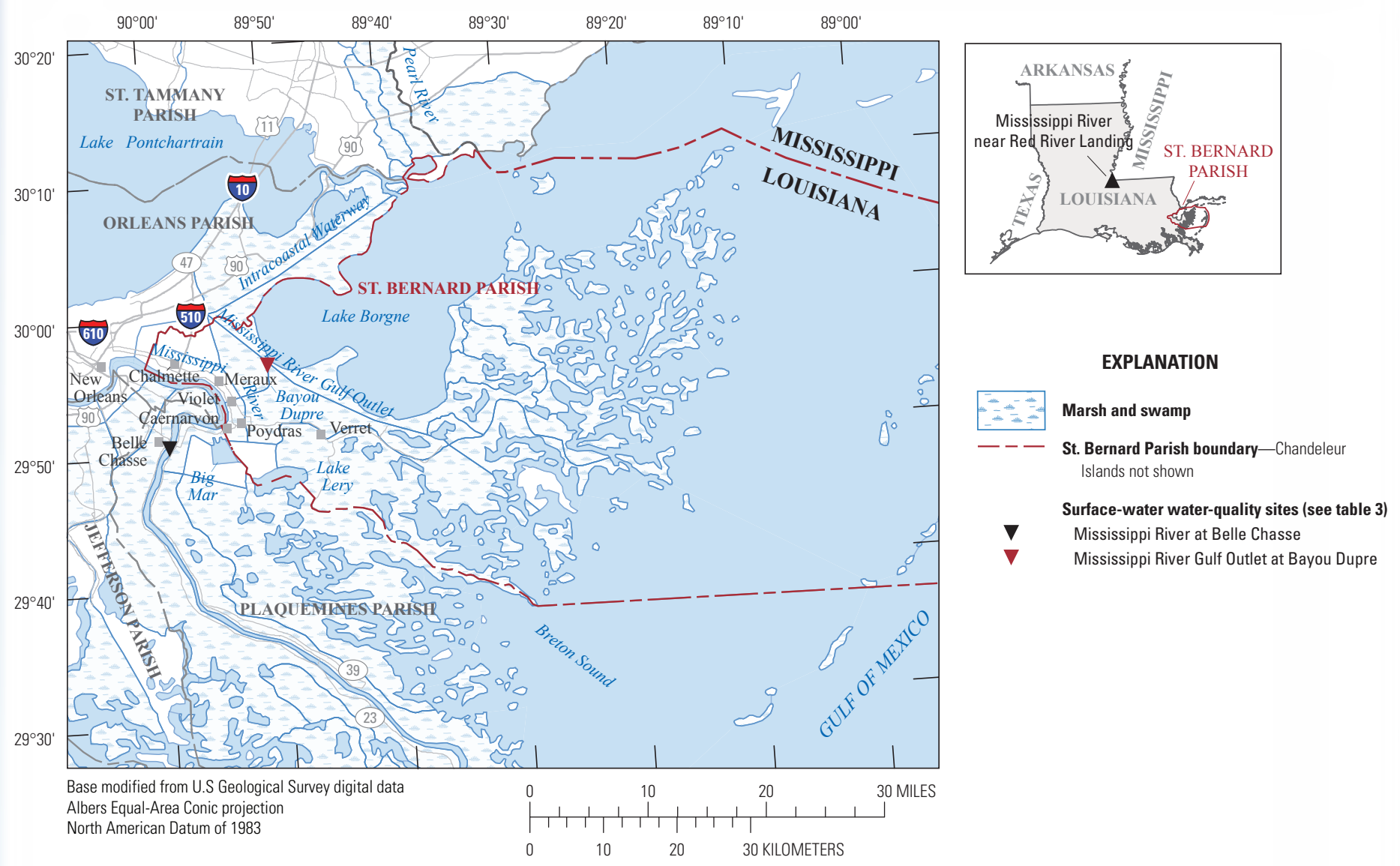

Figure 1. Location of study area, St. Bernard Parish, Louisiana. 
Table 1. Water withdrawals, in million gallons per day, by source in St. Bernard Parish, Louisiana, 2010 (modified from Sargent, 2011).

\begin{tabular}{lcc}
\hline $\begin{array}{c}\text { Aquifer or } \\
\text { surface water body }\end{array}$ & Groundwater & Surface water \\
\hline $\begin{array}{c}\text { Shallow aquifers of the } \\
\text { New Orleans area }\end{array}$ & 0.02 & \\
Mississippi River & & 259.52 \\
$\begin{array}{l}\text { Mississippi River } \\
\text { Gulf Outlet }\end{array}$ & 0.02 & 1.18 \\
Total & & 260.70 \\
\hline
\end{tabular}

Table 2. Water withdrawals, in million gallons per day, by category in St. Bernard Parish, Louisiana, 2010 (modified from Sargent, 2011).

\begin{tabular}{lccc}
\hline \multicolumn{1}{c}{ Category } & Groundwater & Surface water & Total \\
\hline Public supply & 0.00 & 7.82 & 7.82 \\
Industrial & 0.00 & 252.87 & 252.87 \\
Rural domestic & 0.01 & 0.00 & 0.01 \\
Livestock & 0.01 & 0.00 & 0.01 \\
\cline { 2 - 4 } Total & 0.02 & 260.70 & 260.71 \\
\hline
\end{tabular}

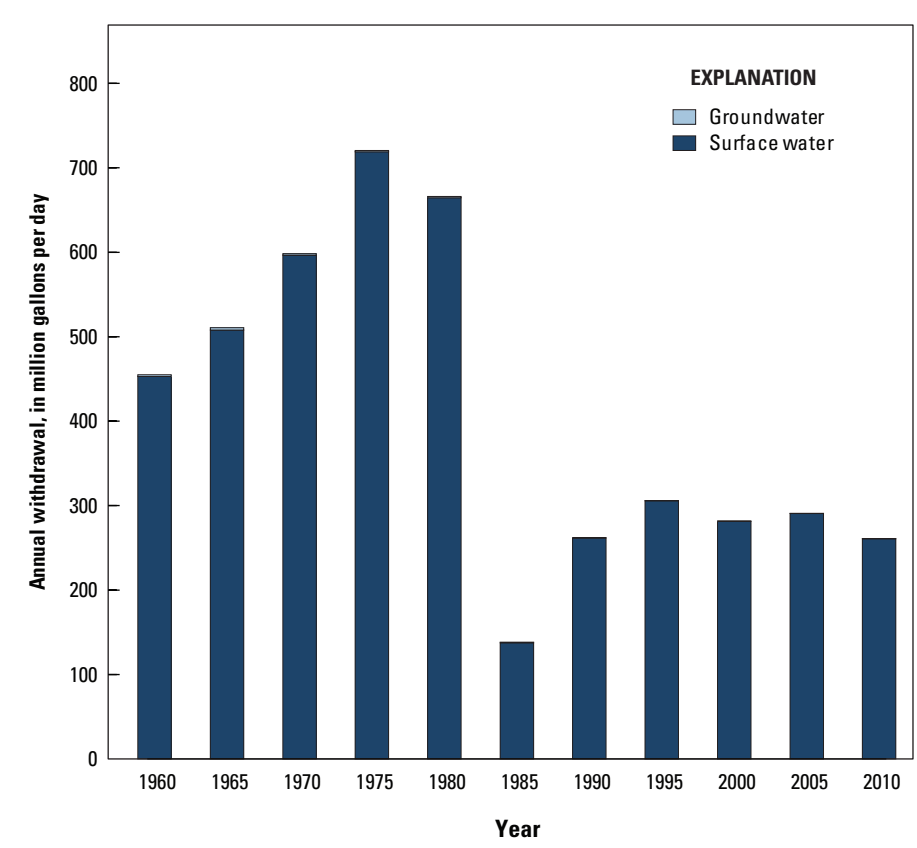

Figure 2. Water withdrawals in St. Bernard Parish, Louisiana,1960-2010.

\section{Groundwater Resources}

Very limited fresh groundwater is available in St. Bernard Parish. Fresh groundwater sources in St. Bernard Parish include Mississippi River point-bar deposits and small areas within the shallow aquifers of the New Orleans area. Deeper aquifers in St. Bernard Parish contain only saltwater (water with a chloride concentration of 250 milligrams per liter $[\mathrm{mg} / \mathrm{L}]$ ). Recharge to aquifers in the parish is from rainfall and leakage from adjacent aquifers and seasonally from the Mississippi River. Discharge from the aquifers is by natural flow into rivers or canals, leakage into adjacent aquifers, and withdrawals from wells. State well-registration records listed eight active water wells in St. Bernard Parish in 2009. In 2010, groundwater withdrawals were for rural-domestic $(0.01 \mathrm{Mgal} / \mathrm{d})$ and livestock (0.01 Mgal/d) uses (table 2).

Point-bar deposits of limited extent are present in St. Bernard Parish along the Mississippi River from near Chalmette to near Meraux. Point-bar deposits are located on the inside of bends in the river and consist of fine to very fine sand and silt. The deposits generally occur at depths between 10 and $30 \mathrm{ft}$ below land surface and may extend to depths of 150 feet (ft) or more. Water levels in point-bar deposits generally fluctuate with the stage of the Mississippi River. Water from point-bar deposits generally is of poor quality because of high iron content (greater than 300 micrograms per liter $[\mu \mathrm{g} / \mathrm{L}]$ ) and very high hardness. ${ }^{2}$ In 2010, there were no reported water withdrawals from pointbar deposits in St. Bernard Parish.

The shallow aquifers of the New Orleans area consist of distributary-channel deposits and discontinuous, nearsurface sands which are present locally in St. Bernard Parish. The extents of these sands generally are limited, and the sands often pinch out over short distances. The shallow aquifers generally contain saltwater, but there are areas where abandoned Mississippi River distributary channel deposits could yield freshwater, such as the abandoned channel located approximately between Poydras and Verret, where rainwater has percolated through the distributary fill into underlying sands and flushed the native saltwater from the sands.

Generally, only small supplies of water can be obtained from these deposits because saltwater underlies the freshwater or is laterally nearby. The freshwater is very hard and has a very high iron content (greater than $300 \mu \mathrm{g} / \mathrm{L}$ ). In 2010, all groundwater withdrawals in St. Bernard Parish came from the shallow aquifers of the New Orleans area and totaled about $0.02 \mathrm{Mgal} / \mathrm{d}$ (table 1 ).

\section{Surface-Water Resources}

In 2010, about $261 \mathrm{Mgal} / \mathrm{d}$ of surface-water were withdrawn in the parish: about $253 \mathrm{Mgal} / \mathrm{d}$ for industrial use and $7.82 \mathrm{Mgal} / \mathrm{d}$ for public supply (table 2). All public-supply water was withdrawn from the Mississippi River, which is

${ }^{2}$ Hardness ranges, expressed as milligrams per liter of calcium carbonate, are as follows: 0-60, soft; 61-120, moderately hard; 121-180, hard; greater than 180, very hard (Hem, 1985). 
the primary source of fresh surface water in the parish. Most surface water withdrawn for industrial use was for cooling purposes and returned to its source after use. The average flow of the Mississippi River near Red River Landing, about 210 river miles upstream of Chalmette (fig. 1, index map), was about 460,000 cubic feet per second (about 298,000 Mgal/d) for 1928-76.

About $260 \mathrm{Mgal} / \mathrm{d}$ were withdrawn from the Mississippi River in St. Bernard Parish in 2010 (table 1). Water samples analyzed during 1977-2009 indicated that water in the Mississippi River at Belle Chasse is generally hard and does not exceed the U.S. Environmental Protection Agency's (EPA) Secondary Maximum Contaminant Levels (SMCLs) ${ }^{3}$ for drinking water for $\mathrm{pH}$ and concentrations of chloride, sulfate, and iron (table 3). Dissolved oxygen is generally greater than $5 \mathrm{mg} / \mathrm{L}$, which is considered the minimum value for a diversified population of fresh, warm-water biota, including sport fish.
In 2010, about $1.18 \mathrm{Mgal} / \mathrm{d}$ were withdrawn from the Mississippi River Gulf Outlet (MRGO) in St. Bernard Parish (table 1) for industrial use. Water samples analyzed during 1978 to 1981 indicated that water in the MRGO at Bayou Dupre (fig. 1) is very hard and generally does not exceed the SMCLs for $\mathrm{pH}$ and iron (table 3 ). The water is saline with chloride concentrations above $250 \mathrm{mg} / \mathrm{L}$. Sulfate concentrations are generally above the SMCL of $250 \mathrm{mg} / \mathrm{L}$. Dissolved oxygen is generally greater than $5 \mathrm{mg} / \mathrm{L}$.

\footnotetext{
${ }^{3}$ The SMCLs are nonenforceable Federal guidelines regarding cosmetic effects (such as tooth or skin discoloration) or aesthetic effects (such as taste, odor, or color) of drinking water. At high concentrations or values, health implications as well aesthetic degradation might exist. SMCLs were established as guidelines for the states by the U.S. Environmental Protection Agency (1992).
}

Table 3. Summary of selected water-quality characteristics for the Mississippi River at Belle Chasse and the Mississippi River Gulf Outlet.

[Values are in milligrams per liter, except as noted. $\mu \mathrm{S} / \mathrm{cm}$, microsiemens per centimeter; ${ }^{\circ} \mathrm{C}$, degrees Celsius; SU, standard units; $\mu \mathrm{g} / \mathrm{L}$, micrograms per liter; $\mathrm{CaCO}_{3}$, calcium carbonate; <, less than; NA, not applicable; SMCL, Secondary Maximum Contaminant Level established by the U.S. Environmental Protection Agency (2012)]

\begin{tabular}{|c|c|c|c|c|c|c|c|c|c|c|}
\hline & $\begin{array}{c}\text { Specific } \\
\text { conduc- } \\
\text { tance, } \\
\text { field }(\mu \mathrm{S} / \mathrm{cm} \\
\left.\text { at } 25^{\circ} \mathrm{C}\right)\end{array}$ & $\begin{array}{l}\text { Oxygen, } \\
\text { dis- } \\
\text { solved }\end{array}$ & $\begin{array}{l}\text { pH, } \\
\text { field } \\
\text { (SU) }\end{array}$ & $\begin{array}{l}\text { Hardness } \\
\text { (as } \mathrm{CaCO}_{3} \text { ) }\end{array}$ & $\begin{array}{c}\text { Calcium, } \\
\text { filtered } \\
\text { (as Ca) }\end{array}$ & $\begin{array}{l}\text { Magne- } \\
\text { sium, } \\
\text { filtered } \\
\text { (as } \mathbf{M g} \text { ) }\end{array}$ & $\begin{array}{l}\text { Sodium, } \\
\text { filtered } \\
\text { (as Na) }\end{array}$ & $\begin{array}{c}\text { Chloride, } \\
\text { filtered } \\
\text { (as CI) }\end{array}$ & $\begin{array}{l}\text { Sulfate, } \\
\text { filtered } \\
\text { (as } \mathrm{SO}_{4} \text { ) }\end{array}$ & $\begin{array}{c}\text { Iron, } \\
\text { filtered, } \\
(\mu \mathrm{g} / \mathrm{L} \\
\text { as } \mathrm{Fe})\end{array}$ \\
\hline \multicolumn{11}{|c|}{ Mississippi River at Belle Chasse, 1977-2009¹ } \\
\hline Median & 408 & 8.2 & 7.7 & 150 & 39 & 12 & 22 & 28 & 48 & 15 \\
\hline 90th percentile & 521 & 11.7 & 7.9 & 180 & 47 & 16 & 36 & 42 & 70 & 42 \\
\hline $\begin{array}{c}\text { Number of } \\
\text { samples }\end{array}$ & 189 & 184 & 188 & 182 & 182 & 182 & 182 & 182 & 182 & 121 \\
\hline $\begin{array}{l}\text { Percentage of } \\
\text { samples that } \\
\text { do not exceed } \\
\text { SMCLs }\end{array}$ & NA & NA & 100 & NA & NA & NA & NA & 99 & 100 & 100 \\
\hline
\end{tabular}

\begin{tabular}{|c|c|c|c|c|c|c|c|c|c|c|}
\hline \multicolumn{11}{|c|}{ Mississippi River Gulf Outlet at Bayou Dupre, 1978-81² } \\
\hline Median & 15,700 & 8.8 & 7.7 & 1,800 & 120 & 360 & 3,000 & 5,400 & 730 & 20 \\
\hline 10th percentile & 8,040 & 6.8 & 7.4 & 910 & 66 & 180 & 1,400 & 2,700 & 370 & $<10$ \\
\hline $\begin{array}{c}\text { Number of } \\
\text { samples }\end{array}$ & 34 & 33 & 34 & 34 & 34 & 34 & 34 & 34 & 34 & 34 \\
\hline \multicolumn{11}{|c|}{ SMCLS } \\
\hline & NA & NA & $6.5-8.5$ & NA & NA & NA & NA & 250 & 250 & 300 \\
\hline
\end{tabular}

${ }^{1}$ Station number 07374525 (U.S. Geological Survey, 2012a; specific data at http://nwis.waterdata.usgs.gov/la/nwis/qwdata/?site_no=07374525).

${ }^{2}$ Station number 295623089501800 (U.S. Geological Survey, 2012b; specific data at http://nwis.waterdata.usgs.gov/la/nwis/qwdata/?site no $=295623089501800$ ). 


\section{Selected References}

Dial, D.C., 1983, Ground-water data for the Mississippi River parishes in the greater New Orleans area, Louisiana: Louisiana Department of Transportation and Development, Office of Public Works Water Resources Basic Records Report no. 11, 47 p.

Hem, J.D., 1985, Study and interpretation of the chemical characteristics of natural water ( $3 \mathrm{~d}$ ed.): U.S. Geological Survey Water-Supply Paper 2254, 264 p., accessed February 20, 2013, at http://pubs.er.usgs.gov/publication/wsp2254.

Louisiana Department of Environmental Quality, 2008, Environmental Regulatory Code, Title 33, Part IX, Subpart 1, accessed June 9, 2009, at http:www.deq.louisiana.gov/portal/ tabid/1674/Default.aspx.

Rollo, J.R., 1966, Ground-water resources of the greater New Orleans area, Louisiana: Department of Conservation, Louisiana Geological Survey, and Louisiana Department of Public Works Water Resources Bulletin no. 9, 69 p.

Sargent, B.P., 2011, Water use in Louisiana, 2010: Louisiana Department of Transportation and Development Water Resources Special Report no. 17, 135 p.

U.S. Environmental Protection Agency, 1992, Secondary Drinking Water Regulations-Guidance for nuisance chemicals: U.S. Environmental Protection Agency publication EPA 810/K-92-001, 4 p., accessed September 28, 2011, at http://water.epa.gov/drink/contaminants/ secondarystandards.cfm.

U.S. Environmental Protection Agency, 2012, 2012 Edition of the drinking water standards and health advisories: U.S. Environmental Protection Agency publication EPA 822-S12-001, Office of Water, 12 p., accessed August 7, 2012, at http://water.epa.gov/action/advisories/drinking/upload/ dwstandards2012.pdf.

U.S. Geological Survey, 2012a, Water quality samples for Louisiana [data for USGS 07374525 Mississippi River at Belle Chasse, La.]: National Water Information System Web Interface, accessed June 2, 2009, at http://nwis.waterdata. usgs.gov/la/nwis/qwdata/?site_no $=07374525$.

U.S. Geological Survey, 2012b, Water quality samples for Louisiana [data for USGS 295623089501800 Chalmette 0030 (MRGO at B. Dupre)]: National Water Information System Web Interface, accessed June 2, 2009, at http://nwis.waterdata.usgs.gov/la/nwis/qwdata/?site_ no $=295623089501800$.

Wells, F.C., 1980, Hydrology and water quality of the lower Mississippi River: Louisiana Department of Transportation and Development, Office of Public Works Water Resources Technical Report no. 21, 83 p.
This fact sheet was published by the U.S. Geological Survey, in cooperation with the Louisiana Department of Transportation and Development (DOTD). Thanks are given to Zahir "Bo" Bolourchi, Director, Water Resources Programs, Louisiana Department of Transportation and Development, who contributed to the content and design of the fact sheet.

\section{By Lawrence B. Prakken}

\section{For additional information, contact:}

Director, USGS Louisiana Water Science Center 3535 S. Sherwood Forest Blvd., Suite 120

Baton Rouge, LA 70816

E-mail: dc_la@usgs.gov

Fax: (225) 298-5490

Telephone: (225) 298-5481

Home Page: http://la.water.usgs.gov 